\title{
Aposentadoria rural especial e a dinamização no comércio local em Boa Esperança - PR
}

\author{
Special rural retirement and the dynamization in local trade in Boa \\ Esperança - PR
}

\author{
Claudia Chies', Ana Cristina da Silva"l
}

\section{RESUMO}

O presente artigo tem por finalidade apresentar uma reflexão sobre os impactos da aposentadoria rural especial na melhoria das condições de vida de beneficiários e familiares e na dinamização do comércio local no município de Boa Esperança - PR. A pesquisa foi desenvolvida por meio de estudos bibliográficos, levantamento de dados estatísticos, aplicação de questionários a aposentados rurais, realização de entrevistas com representantes de entidades locais e comerciantes. O problema da pesquisa está em levantar as principais características socioeconômicas dos aposentados rurais; compreender se houve melhorias significativas nas condições de vida dos agricultores e familiares após aposentarem-se; e avaliar se os recursos oriundos da aposentadoria rural especial têm impactado a dinamização do comércio do município. Os resultados alcançados mostraram que o público aposentado rural é formado em sua maioria por pequenos proprietários de terra e que a aposentadoria rural, apesar do baixo valor do salário mínimo, é tida pela maioria dos aposentados como fator de mudanças positivas em suas vidas, pois gera estabilidade financeira à família e amplia significativamente a renda. Além disso, os recursos previdenciários geram dinamização do comércio local, contribuindo para processos de desenvolvimento.

Palavras-chave: Aposentadoria Rural Especial; Dinamização do comércio Local; Boa Esperança - PR

\section{ABSTRACT}

The purpose of this article is to reflect about the special rural retirement impacts on the improvement in the living conditions of the beneficiaries and family, and on the dynamization of local trade in Boa Esperança town - PR. The research was developed through bibliographical studies, collection of statistical data, application of questionnaires to rural retirees, interviews with representatives of local entities and traders. The research problem is to raise the main socioeconomic characteristics of rural retirees; understand whether there have been significant improvements in the living conditions of farmers and their families after retirement; and to evaluate if the resources coming from the special rural retirement have impacted the town's commerce dynamization. The results show that the rural retired public is formed mostly by small landowners, and that rural retirement, despite the low minimum salary, is considered by the majority of retirees as a factor of positive changes in their lives, since it generates financial stability to the family and significantly increases income. In addition,

'Professora Assistente da Universidade Estadual do Paraná, Campus de Campo Mourão. E-mail: claudiachies@hotmail.com

"Especialista em Geografia, Meio Ambiente e Ensino pela Unespar, Campus de Campo Mourão e em Metodologia de Ensino de Geografia e História. E-mail: 7silva.a.c@gmail.com ORCID: https://orcid.org/0000-0003-2800-8322 
pension resources from rural pensions generate dynamism of local commerce, contributing to development processes.

Keywords: Special Rural Retirement; Promotion of local commerce; Boa Esperança - PR

\section{INTRODUÇÃO}

Os temas vinculados à aposentadoria têm se mostrado emergentes na atualidade, pois o Brasil passa por um período de reforma previdenciária. A partir dessa perspectiva, quando se trata a respeito dos aposentados rurais, suscita-se questões como a transição demográfica brasileira, cujos idosos representam um percentual cada vez mais significativo da população, não se pode deixar de abarcar as demandas que envolvem a valorização e o respeito a essa parcela da população.

Com base na vivência e convivência no campo de estudo, verificou-se que o município de Boa Esperança possui um histórico de representatividade da agricultura familiar com significativo grupo de agricultores aposentados. Assim, o objetivo da pesquisa foi analisar o impacto da aposentadoria rural especial na melhoria das condições de vida dos beneficiários e familiares, considerando a importância da previdência rural para a dinamização do comércio local no município de Boa Esperança - PR.

Nesse sentido, levantam-se os seguintes questionamentos para a pesquisa: 1) Quais as principais características socioeconômicas dos aposentados rurais no município estudado? 2) Há melhorias significativas nas condições de vida dos agricultores ao se aposentarem? 3) O benefício gera impactos na vida apenas do beneficiário ou abrange o contexto familiar? 4) A aposentadoria rural especial tem impacto na dinamização do comércio de Boa Esperança?

A pesquisa mostra-se ainda importante tendo em vista que há poucos trabalhos elaborados sobre o município em estudo e acerca do tema. Portanto, busca-se promover reflexão sobre um tema atual e contribuir no âmbito do levantamento de dados para ampliar e produzir conhecimento acadêmico e científico. 
Boa Esperança é um município brasileiro do Estado do Paraná que se localiza na Mesorregião Centro Ocidental Paranaense, como é possível visualizar no Mapa 1.

\section{Mapa 1 - Localização do município de Boa Esperança - PR}

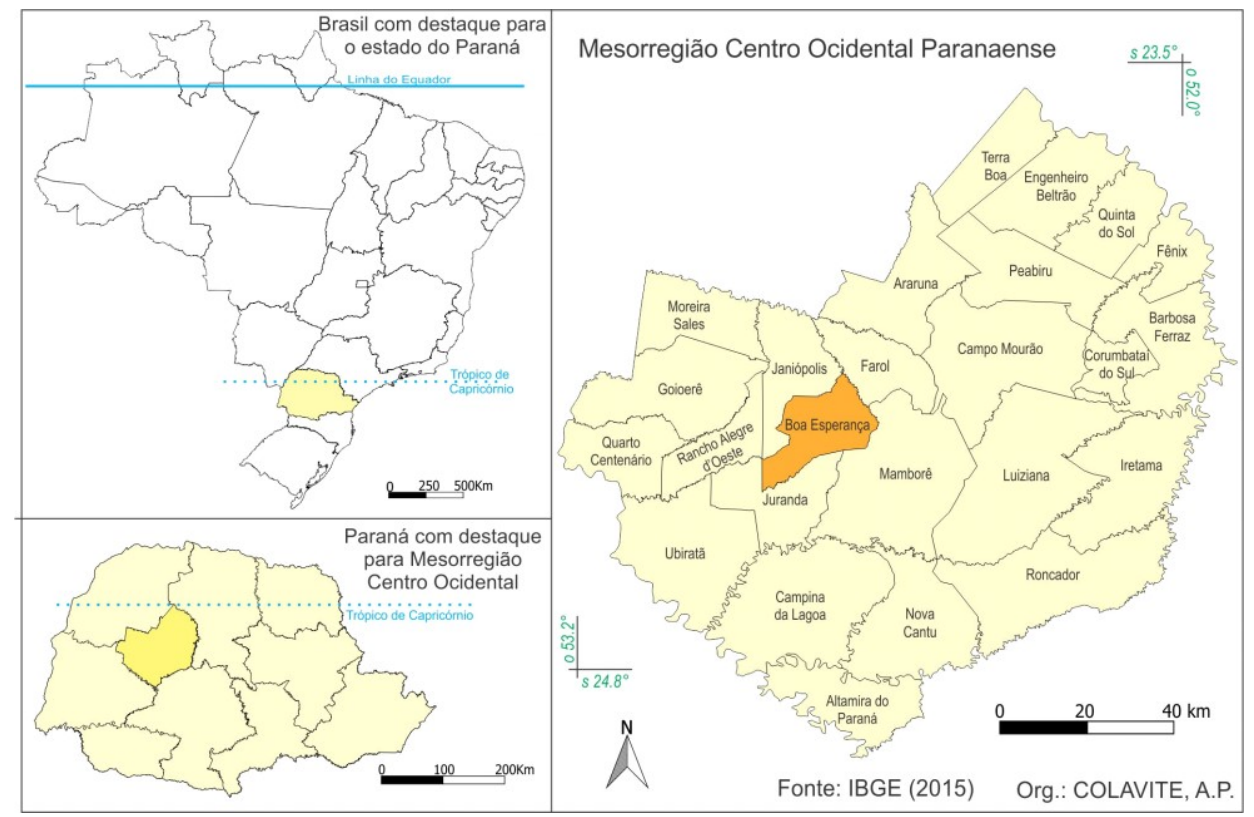

Fonte: Adaptado de Colavite (2018).

Segundo dados da Prefeitura Municipal de Boa Esperança (2017), em 1950, havia um considerável crescimento demográfico e econômico, com casas de comércio espalhando-se ao longo da rua principal. Em 27 de Janeiro de 1951, por meio da Lei Estadual $n^{\circ}$ 613, foi criado o distrito de Barreiro do Oeste. Em 6 de março de 1964, o Governador Ney Braga sancionou a Lei Estadual n 4844, criando o município, que teve seu nome alterado para Boa Esperança por sugestão da própria comunidade, simbolizando o otimismo dos colonizadores que acreditavam em um futuro melhor. O município foi instalado oficialmente em 14 de dezembro de 1964, sendo desmembrado dos municípios de Janiópolis e Mamborê.

Em relação ao processo de colonização e desenvolvimento do município, Gotardo relatou que sua família chegou ao município em 1978 para trabalhar no Instituto Paranaense de Assistência Técnica e Extensão Rural (EMATER). Explicou 
que a agricultura nesse período "era bem empírica", voltada para o cultivo de algodão, café, amendoim, mamona, soja, milho, trigo, sendo mais diversificada. Enfatizou que era bem diferente da agricultura moderna e tecnificada que se encontra hoje. Ressaltou, ainda, que, na atualidade, a agricultura no município encontra-se concentrada em três culturas: soja, milho e trigo. Gotardo avaliou que "quem 'não evoluiu' acabou vendendo a pequena propriedade e foi embora para outra região, então, durante esse processo de modernização muitas famílias foram embora do município" (informação oral).

Segundo dados do Instituto Brasileiro de Geografia e Estatística (IBGE), a população estimada do município de Boa Esperança em 2018 é de 4.165 habitantes. Costa (2013) estabeleceu a noção de munícipios periféricos a partir dos 399 municípios paranaenses, analisando quatro critérios: dependência econômica, subordinação territorial, indicadores sociais críticos e esvaziamento populacional. Nessa classificação, Boa Esperança, atualmente, pode ser considerado como um município periférico. No Gráfico 1 pode-se visualizar um parâmetro da evolução populacional do município entre os anos de 1991 e 2018.

\section{Gráfico 1 - Evolução Populacional no município de Boa Esperança, de 1991 a 2018.}

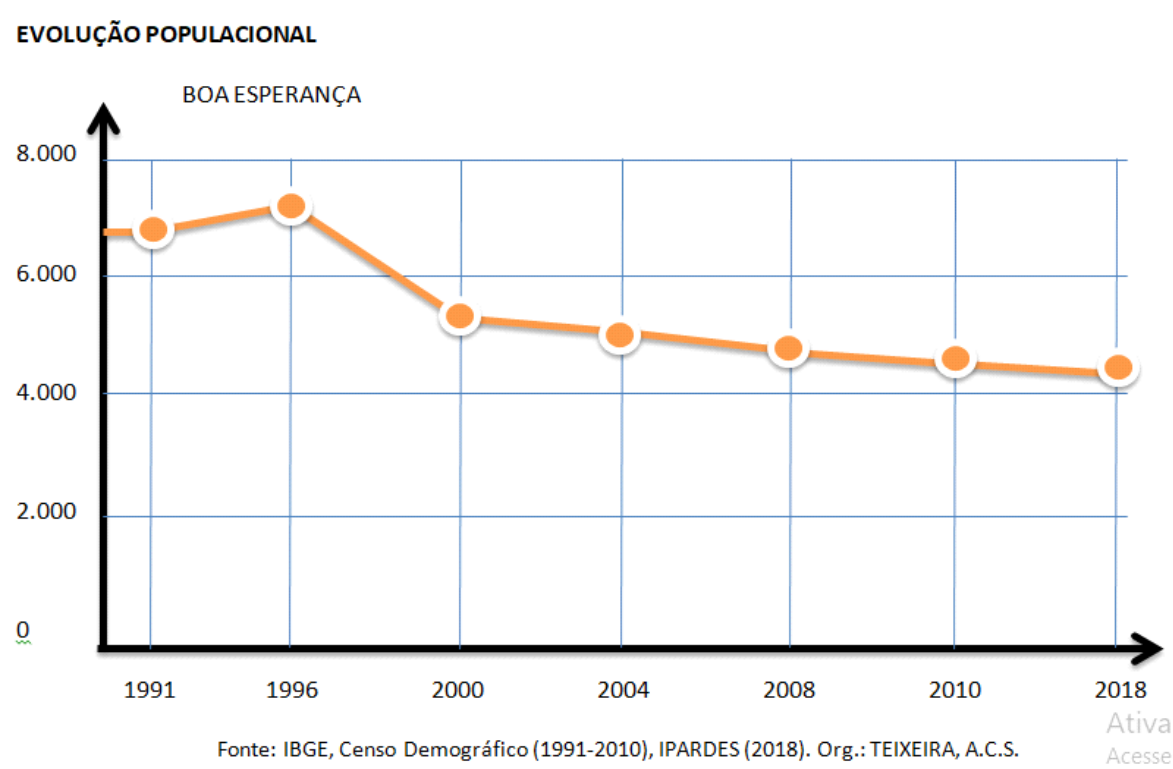

Fonte: Adaptado de Ipardes (2018). 
Como se observa, houve uma queda representativa no número de habitantes de 1991 para 2018, que ocorreu atrelado às transformações pelas quais o município passou, sobretudo devido ao processo de modernização agrícola que levou à diminuição da mão de obra no campo, gerando intenso êxodo rural, processo que ocorreu em todo o Estado do Paraná.

Tal processo modificou a estrutura fundiária, no qual um grande número de pequenas propriedades foram adquiridas por grandes produtores de soja, milho e trigo para compor propriedades maiores. Assim, inúmeras famílias de pequenos produtores rurais migraram para outras regiões após venderem suas propriedades, especialmente a população jovem e adulta, que se deslocou para centros urbanos maiores em busca de oportunidades de educação formal e trabalho, já que o município não absorveu a mão de obra oriunda do meio rural.

Desse modo, atualmente, há um significativo número de população idosa no município, principalmente aposentados. Como é possível observar no Gráfico 2, o índice de envelhecimento da população do município teve gradativo crescimento nas últimas décadas, o que corrobora a análise que propõe-se.

\section{Gráfico 2 - Índice de envelhecimento da população de Boa Esperança - PR (1980-} 2000)

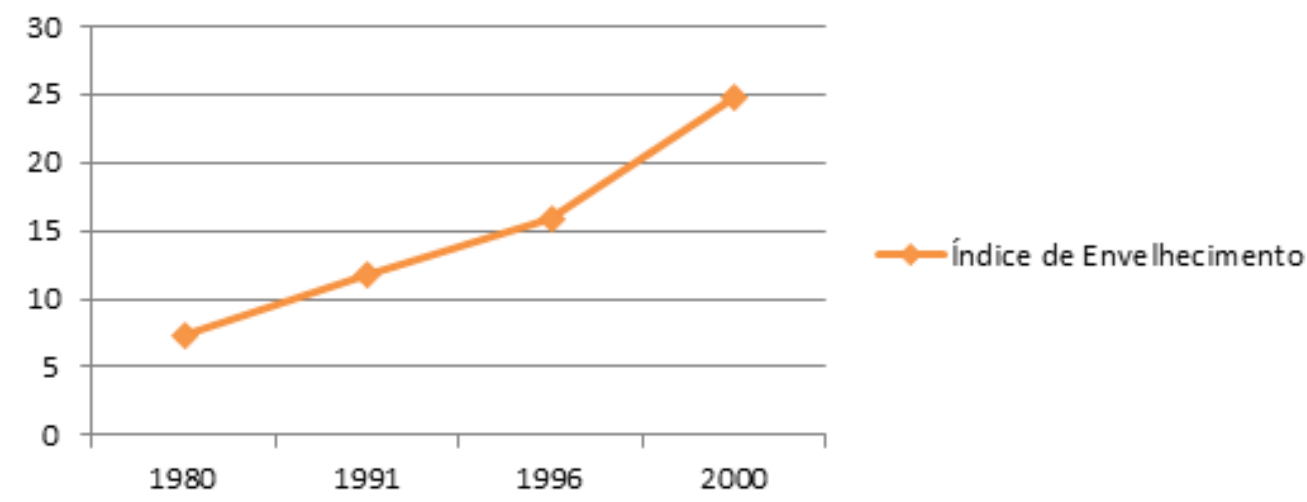

Fonte: Ipardes (2019).

Assim, estrutura-se o artigo em três partes principais. Na primeira, apresenta-se os procedimentos metodológicos adotados; na segunda, realiza-se 
levantamento teórico sobre a temática; e, na terceira, expõe-se a análise dos resultados obtidos com a pesquisa.

\section{PROCEDIMENTOS METODOLÓGICOS}

A presente pesquisa foi desenvolvida na perspectiva crítico-dialética, estudando as relações que envolvem a sociedade e compreendendo-as de modo dinâmico, contraditório e histórico. Além disso, trabalhou-se com a perspectiva quali-quantitativa, ou seja, com dados qualitativos e quantitativos, pois se compreende que são essenciais e complementares.

O primeiro passo para a realização da pesquisa foi o levantamento, estudo e análise crítica de referenciais teóricos. Também foram realizados levantamentos de dados estatísticos junto a órgãos de pesquisa como o IBGE, Instituto Paranaense de Desenvolvimento Econômico e Social (IPARDES) e Prefeitura Municipal de Boa Esperança.

A fim de obter dados primários, foram realizadas visitas in loco para aplicação de questionários complementados com entrevistas a 14 aposentados rurais do município de Boa Esperança (Figura 1). Os trabalhos a campo ocorreram nos dias 03, 17, 18 e 19 de março e 08 e 09 de abril de 2018.

A escolha pela técnica da aplicação de questionários aos aposentados devese ao fato de serem mais objetivos, possibilitando levantar maior número de informações em um tempo limitado. Segundo Gil (2008), o questionário é uma técnica de investigação formulada por um conjunto de questões que são aplicadas a pessoas com o propósito de obter informações, que podem estar vinculadas a crenças, valores, sentimentos, expectativas, conhecimento, entre outros.

Na maioria das pesquisas, os questionários são auto aplicados, propostos de forma escrita aos informantes. Entretanto, no desenvolvimento desta pesquisa, optou-se para que o pesquisador formulasse as questões oralmente aos participantes, visto que o grupo a ser estudado trata-se de pessoas aposentadas, idosas e, em geral, com baixa ou nenhuma escolaridade, o que dificulta/inviabiliza a auto aplicação. 
Figura 1 - Aplicação de alguns questionários aos aposentados rurais e assinatura da ficha de autorização do uso das informações e imagens - março/abril de 2018

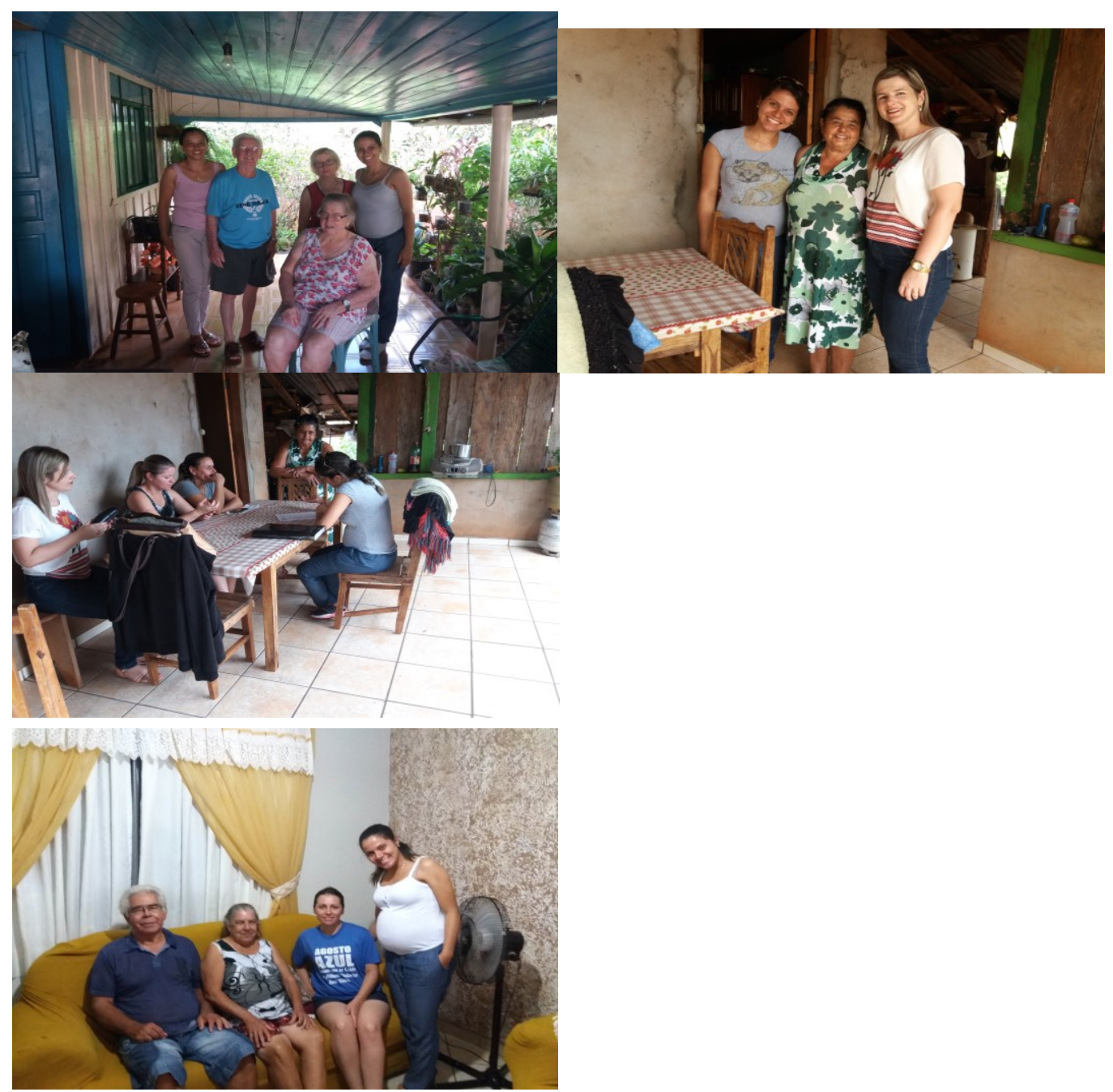

Fonte: Acervo particular das autoras.

Para a aplicação dos questionários ao grupo estudado, optou-se por um sistema de amostragem por tipicidade ou intencional. Para Gil (2008), a amostragem por tipicidade ou intencional se trata de uma amostragem não probabilística que consiste em selecionar um subgrupo da população, cuja base das informações disponíveis possa resultar em um representativo de toda a população. De acordo com Chies (2017), os aposentados rurais constituem um público homogêneo, com condições e histórias de vida similares, o que propicia trabalhar com a amostragem por tipicidade. Ressalta-se que, para o trabalho de campo, buscou-se distribuir a aplicação dos questionários em todo o território do município, tanto na área rural como urbana. Torna-se ainda importante explicar 
que o questionário utilizado e os resultados obtidos foram tabulados com o software Sphix Plus Lexica, que contribui para a tabulação dos dados obtidos, gerando gráficos e tabelas.

Também foram realizadas entrevistas semiestruturadas com 3 representantes locais e 4 comerciantes, (Figura 2):

Figura 2 - Entrevistas realizadas com alguns representantes locais, comerciantes e assinatura da ficha de autorização do uso das informações e imagens - março/abril de 2018
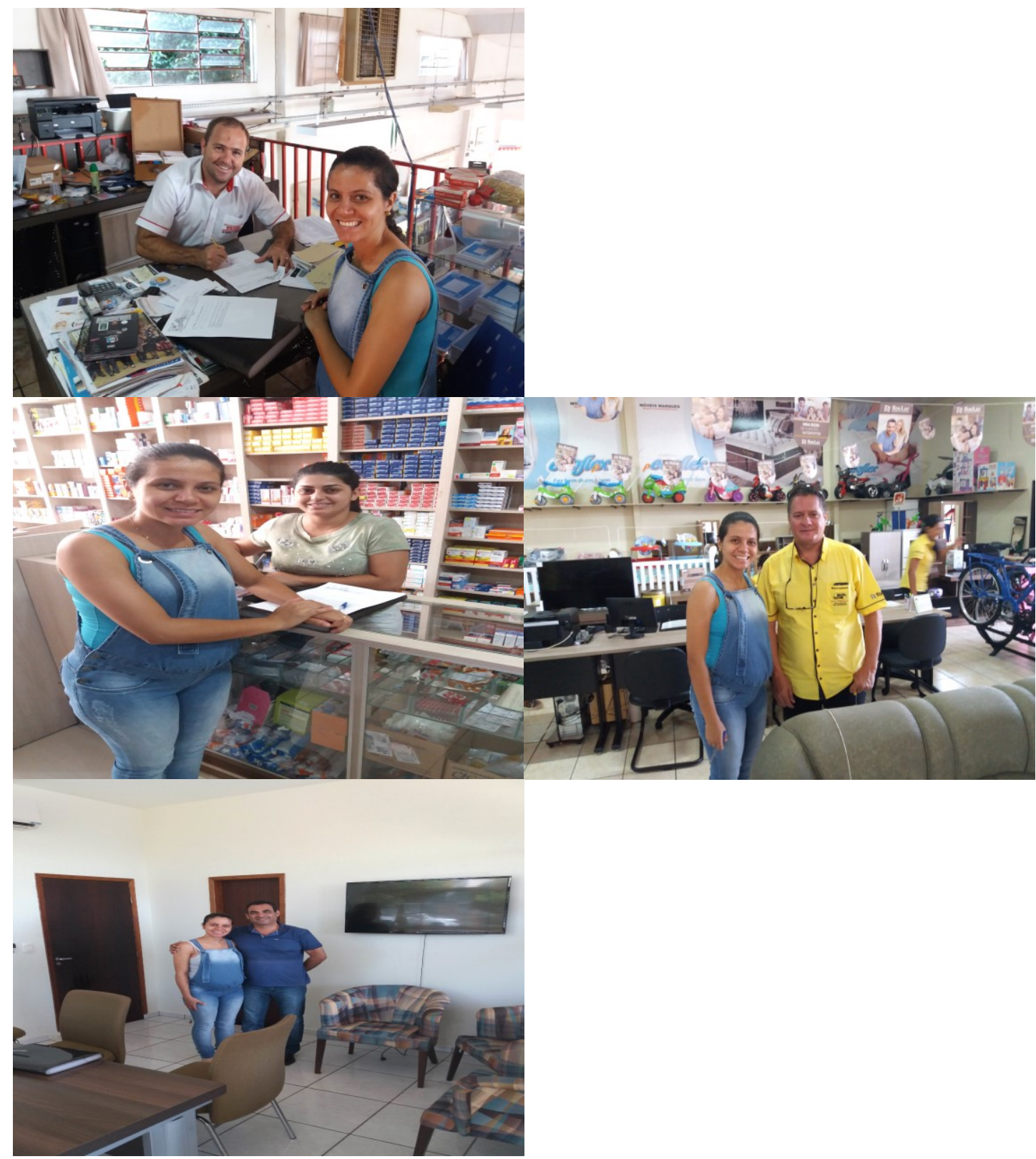

Fonte: Acervo particular das autoras. 
A entrevista semiestruturada, de acordo com Gil (2008), dá-se por meio de uma relação de pontos de interesse do entrevistador, ou seja, apresenta certo grau de estruturação e o entrevistador vai explorando as questões no decorrer da entrevista. Dessa maneira, o entrevistado pode falar livremente, entretanto, se este se afastar muito do tema proposto o entrevistador intervém, de forma suficientemente sutil, com o intuito de preservar a espontaneidade do entrevistado e seu objetivo com a obtenção de dados. Cabe salientar que todos os participantes da pesquisa autorizaram o uso das informações e fotografias para fins de pesquisa acadêmica.

Após a coleta dos dados, as informações foram tabuladas e organizadas a partir de gráficos e tabelas para análise em busca de promover reflexão sobre a relação do benefício previdenciário, as condições de vida dos aposentados e a influência para a dinamização do comércio local.

\section{O ENVELHECIMENTO DA POPULAÇÃO E A APOSENTADORIA RURAL ESPECIAL}

Estudos apontam que a dinâmica demográfica vem sendo modificada nas últimas décadas, tanto em âmbito municipal, como estadual e nacional. É possível verificar esse aspecto ao se analisar os levantamentos mais recentes realizados pelo IBGE, como pode ser visualizado nas pirâmides etárias (Figura 03), com base no Censo Demográfico realizado em 2010.

\section{Figura 03 - Pirâmides Etárias de Boa Esperança, do Paraná e do Brasil (2010)}
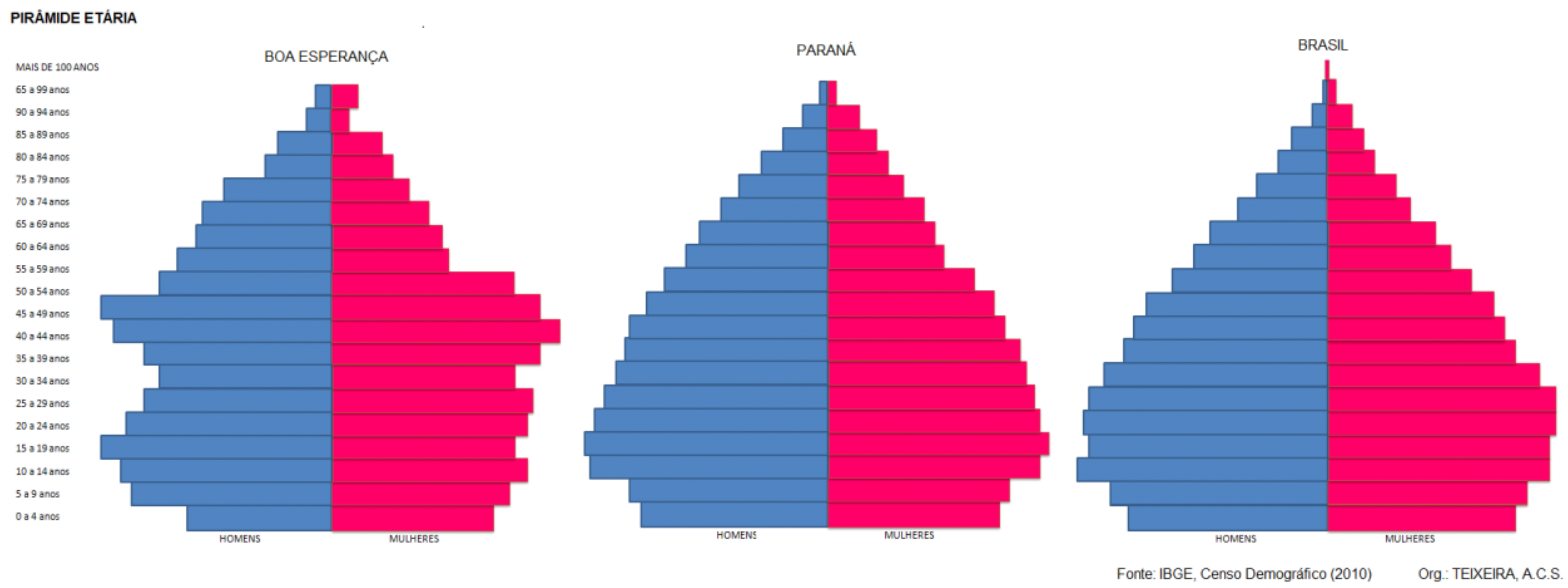

Fonte: Adaptado de IBGE (2010). 
Analisando as pirâmides etárias apresentadas na Figura 3, avalia-se que há uma redução na base, o que significa que decaiu a taxa de natalidade em nível municipal, estadual e nacional. Também verifica-se aumento no topo, mostrando um processo de envelhecimento da população e aumento gradual na expectativa de vida. Há, além disso, diminuição, no município de Boa Esperança, da população entre 20 a 39 anos, principalmente masculina, provavelmente vinculada à busca por educação formal e trabalho em cidades maiores.

As mudanças na estrutura etária da população relacionam-se a uma série de fatores, tais como: a urbanização brasileira; os avanços na medicina; a inserção da mulher no mercado de trabalho; o uso de métodos contraceptivos, dentre outros. Nesse contexto, destaca-se o aumento da população idosa, que gera a necessidade de mais estudos sobre esse grupo a respeito de seus direitos, acessibilidade, serviços de saúde, lazer, previdência social entre outros temas.

Sobre a dinâmica demográfica brasileira vale ressaltar que

\begin{abstract}
A população brasileira vem apresentando uma nova dinâmica demográfica, com um ritmo cada vez mais lento de crescimento populacional, configurando um novo perfil etário da população, onde se destacam os percentuais elevados de participação da população adulta e com mais de sessenta anos. Portanto, com um perfil cada vez mais idoso, resultante da combinação da queda na taxa de mortalidade e também da taxa de fecundidade. [...] a cada ano o país possui mais idosos e que eles se distribuem nas diferentes camadas, segmentos ou classes sociais, vivendo a sua velhice de forma diferente entre si, dependendo do contexto sócio-econômico onde cada um se encontra inserido. Isto também é válido para a diferenciação entre idosos que vivem no meio urbano ou no meio rural [...] (ALBUQUERQUE; LÔBO; RAYMUNDO, 1999, p. 02).
\end{abstract}

Nesse sentido, Alves (2008, p. 3) afirma que “há uma forte mudança na estrutura etária das pirâmides populacionais, pois a expectativa de vida média em 1900 era de apenas 30 anos, já em 2000 ultrapassou os 60 anos". Diante do exposto, faz-se importante a discussão acerca da aposentadoria rural especial.

Para Delgado e Cardoso Jr. (1999, p. 293), o processo de aposentadoria rural especial ocorreu tardiamente no Brasil, visto que demorou quase meio século desde a promulgação da Lei Eloi Chaves, que ocorreu em 1923, 
regulamentando a criação das Caixas de Aposentadorias e Pensões (CAP) dos trabalhadores urbanos, para então se criar um sistema de assistência aos idosos e inválidos do setor rural. Sobre a previdência rural, os autores explicitam que

\begin{abstract}
Tal sistema, inaugurado pela Lei Complementar $n^{\circ} 11$, de 1971, e implantado a partir de 1972 com o Programa de Assistência ao Trabalhador Rural/Fundo de Assistência e Previdência do Trabalhador Rural (Prorural/Funrural), assistia os trabalhadores rurais, os pescadores (a partir de 1972) e os garimpeiros (a partir de 1975), oferecendo benefícios precários de aposentadoria por idade aos 65 anos, limitados ao homem, cabeça do casal e tendo meio salário mínimo como teto (DELGADO; CARDOSO JR, 1999, p. 293).
\end{abstract}

Sendo assim, o benefício previdenciário era precário e limitava-se, na maior parte dos casos, apenas aos homens, tidos como "o cabeça" do casal. Porém, o trabalho abrangia, na maioria das vezes, todo o contexto familiar. Mudanças significativas na aposentadoria rural ocorreram apenas a partir da Constituição Federal de 1988, no qual no Art. 194, § $8^{\circ}$, promulga que

$\S 8^{\circ} \mathrm{O}$ produtor, o parceiro, o meeiro e o arrendatário rurais e o pescador artesanal, bem como os respectivos cônjuges, que exerçam suas atividades em regime de economia familiar, sem empregados permanentes, contribuirão para a seguridade social mediante a aplicação de uma alíquota sobre o resultado da comercialização da produção e farão jus aos benefícios nos termos da lei (BRASIL, 1988, on-line).

Nesse sentido, compreende-se que só houve melhoras nas condições do benefício previdenciário rural a partir da Constituição de 1988, de forma que se introduziu o princípio de acesso universal para ambos os sexos, assim como se estabeleceu alguns critérios de acesso ao benefício. O Art. 201, da Constituição Federal de $1988, \S 7^{\circ}$, define que

É assegurada aposentadoria no regime geral de previdência social, nos termos da lei, obedecidas as seguintes condições: [...] II - sessenta e cinco anos de idade, se homem, e sessenta anos de idade, se mulher, reduzido em cinco anos o limite para os trabalhadores rurais de ambos os sexos e para os que exerçam suas atividades em regime de economia familiar, nestes incluídos o produtor rural, o garimpeiro e o pescador artesanal (BRASIL, 1988, on-line).

Augusto e Ribeiro (2005, p. 200) abordam que o processo de envelhecimento trouxe à tona uma discussão sobre o novo ator social, o idoso 
aposentado rural, a partir da Constituição de 1988 incluído no Regime Geral da Previdência Social.

Apesar da paridade entre os gêneros no direito ao benefício previdenciário rural, a partir da Constituição Federal de 1988, Chies (2017) assegura que ainda há maior dificuldade de acesso aos benefícios da previdência social por parte das mulheres agricultoras, visto que na comercialização dos produtos as notas fiscais, geralmente são emitidas no nome dos homens, pois ainda são vistos, na maioria dos casos, como os responsáveis pela atividade produtiva, dificultando a comprovação no trabalho rural por parte das mulheres. Contudo, a autora salienta que já é possível notar avanços ao se analisar as últimas décadas no que tange a esse problema.

O que se evidencia, também, é uma significativa melhora na vida dos agricultores familiares ao passar a receber o benefício previdenciário. Sobre dessa questão, Schwarzer (2000) entende que os benefícios valorizam a posição dos idosos nas famílias, pois ganham autonomia financeira, e permitem que, em muitos casos, essas famílias possam ajudar filhos e netos. Embora um salário mínimo seja pouco, ele se constitui em uma fonte de renda fixa, fundamental na vida desses idosos. Assim, o idoso passa a ser visto com mais respeito pelos membros da família e em âmbito comunitário.

Refletindo acerca disso, Chies (2017) aponta que há uma revalorização dos idosos por meio da aposentadoria rural, especialmente nas áreas mais pobres. Entretanto, defende que a valorização do idoso deve ocorrer por meio do reconhecimento de sua experiência e vivência, pois entende o envelhecimento como uma condição biológica da vida humana, assim, todos podem e/ou deveriam alcançar essa fase da vida, sendo que conseguir chegar a ela deve ser visto como uma conquista. Ressalta, ainda, que o acesso ao benefício previdenciário rural tem se mostrado um instrumento fundamental de inserção dos idosos e de seus familiares em condições de sobrevivência mais dignas. 
Albuquerque, Lôbo e Raymundo (1999) também ressaltam a valorização do idoso proporcionada pela aposentadoria, pois, por mais que na zona rural o idoso ainda mantem certo nível de respeitabilidade perante os familiares, muitas vezes, era tido como um "fardo" para seus parentes mais próximos. A partir do momento em que os mesmos passam a ter uma renda fixa, passam a ter mais aceitabilidade na família. Delgado e Cardoso Jr. (1999) corroboram que o acesso à previdência traz uma revalorização dos idosos, visto como uma espécie de salvaguarda da subsistência familiar. Isso altera o papel de assistidos pelos familiares para assistentes, considerando que outras pessoas da família também podem desfrutar da renda fixa que os idosos passam a ter desfrutar.

Em contrapartida, vale refletir que há inúmeros casos de violência financeira, inclusive familiar, em relação aos idosos e/ou aposentados, como apropriação de aposentadoria, coação a dar dinheiro ou a fazer empréstimos, induzir o idoso ao erro ou a comprar algum produto. Explicita-se que nesta pesquisa, bem como em outras por nós realizada com aposentados rurais, não se constatou situações de exploração. No entanto, elucida-se que esse também não foi o foco. Porém, acredita-se que existam casos de exploração. Compreende-se que, na maioria dos casos pesquisados, há um processo de mútua colaboração familiar em que os recursos da previdência acabam somando no contexto familiar, extrapolando a figura do aposentado, sem exploração.

Nesse sentido, pode-se avaliar que os idosos ganham maior visibilidade perante alguns familiares e até mesmo no grupo social ao qual se inserem, pois os mesmos adquirem mais autonomia e passam a contribuir com a dinamização econômica em suas residências e nos municípios onde residem.

\section{ANÁLISE DOS RESULTADOS}

Com base na vivência e convivência com o campo de estudo verificou-se que o município de Boa Esperança possui um histórico com relevância da 
agricultura familiar. Para Chies (2017), a agricultura familiar é a atividade agropecuária realizada, em sua maior parte, pelos membros da família, em minifúndios e pequenas propriedades, de forma que a maior parte da renda familiar seja proveniente das atividades agropecuárias desenvolvidas na propriedade rural.

Destaca-se, na atualidade, uma quantidade representativa de aposentados rurais especiais, ou seja, agricultores em regime de economia familiar aposentados, no município de Boa Esperança. É importante enfatizar que esta categoria de aposentadoria é direito das agricultoras a partir dos 55 anos e dos agricultores a partir dos 60 anos. Diante dos aspectos expostos, apresenta-se a representatividade da faixa etária de homens e mulheres acima de 55 anos no município de Boa Esperança (Tabela 01).

\section{Tabela 01 - População censitária com mais de 55 anos, segundo faixa etária e sexo} (2010)

\begin{tabular}{cccc}
\hline Faixa Etária (anos) & Masculina & Feminina & Total \\
\hline De 55 a 59 & 115 & 103 & 218 \\
De 60 a 64 & 97 & 101 & 198 \\
De 65 a 69 & 93 & 86 & 179 \\
De 70 a 74 & 74 & 63 & 137 \\
De 75 a 79 & 36 & 41 & 77 \\
Acima de 80 & 39 & 44 & 83 \\
Total & 339 & 438 & 892 \\
\hline
\end{tabular}

Fonte: Adaptado de IBGE (2010).

Considerando a faixa etária acima de 55 anos, evidencia-se que o percentual (em torno de $20 \%$ ) é representativo em relação à população total de 4.438 habitantes, estimados pelo IBGE em 2016 para o município de Boa Esperança.

Como já exposto nos procedimentos metodológicos, procedeu-se à aplicação de questionários a aposentados rurais do município de Boa Esperança. Entre os 14 participantes da pesquisa, 8 (57\%) foram do sexo masculino e 6 (43\%) foram do sexo feminino. 
Quanto à faixa etária (Gráfico 03), 7 (50\%) pessoas têm entre 56 e 65 anos, 5 (36\%) entre 66 e 75 anos, 1 (7\%) entre 76 e 85 anos e $1(7 \%)$ entre 86 e 95 anos. Não tivemos nenhum caso com menos de 55 anos ou mais de 95 anos. Quanto ao estado civil, 12 (86\%) são casados, 1 (7\%) vive em união estável e 1 (7\%) é viúvo.

\section{Gráfico 03 - Faixa etária dos participantes da pesquisa}

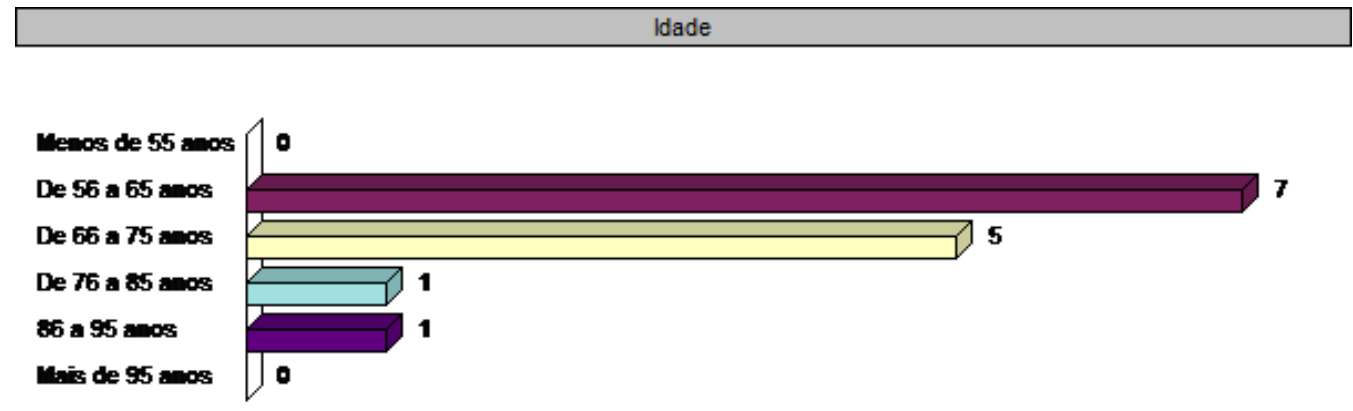

Fonte: Pesquisa de campo (2018).

Em relação à escolaridade, 12 (86\%) declararam ter os anos iniciais do ensino fundamental incompleto e 2 (14\%) não têm nenhuma escolaridade. Ressalta-se que a maioria afirmou ser muito difícil ter acesso à escola durante seus períodos de infância e adolescência, pois havia poucas escolas e eram distantes. Além disso, que começaram a trabalhar muito cedo na roça e que seus pais não tinham a compreensão de que seus filhos precisassem estudar. Ou seja, evidenciamos a baixa escolaridade desse público e uma inserção prematura no mundo do trabalho.

Dentre os participantes da pesquisa, 6 (43\%) vivem na área urbana, 5 (36\%) vivem na área rural e 3 (21\%) vivem em área periurbana. 11 (79\%) relataram viver na região a mais de 30 anos, 2 (14\%) entre 6 a 10 anos e 1 (7\%) entre 21 a 30 anos. Com esta informação sobre o tempo de residência no local, constatamos um forte enraizamento territorial deste público, junto ao sentimento de pertencimento ao lugar. 
Com relação à forma de acesso a terra (Gráfico 04) 13 (93\%) afirmaram ser proprietários da terra, desses, 2 ainda ressaltaram que também cultivam terras como arrendatários, apenas 1 (7\%) declarou que nunca possuiu terra, e trabalhou como boia-fria.

\section{Gráfico 04 - Forma de acesso a terra como agricultor familiar.}

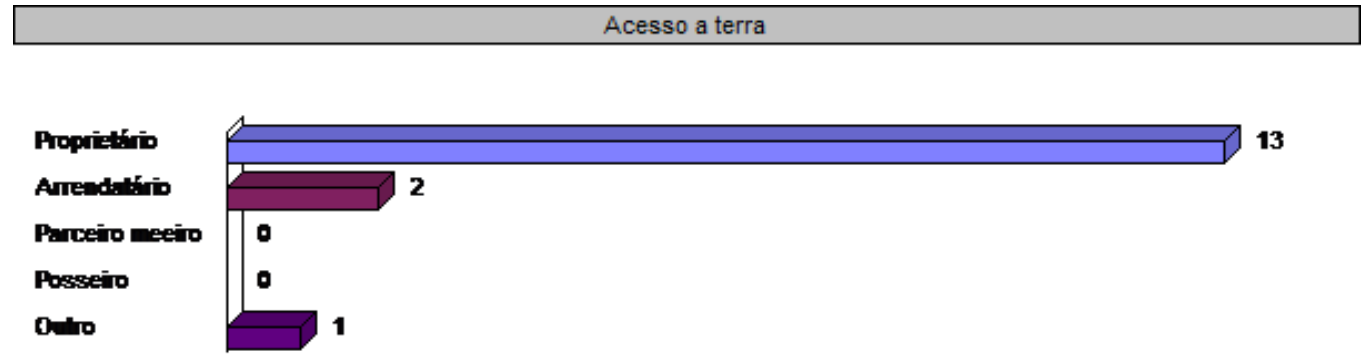

Fonte: Pesquisa de campo (2018).

No que se refere à renda familiar dos participantes (Gráfico 05), verificamos que em 3 casos (24\%), a renda está na faixa de 3 salários mínimos mensais, 2 (14\%) 2 salários, 2 (14\%) entre 2 salários e meio, 2 (14\%) entre 4 à 5 salários, 1 (7\%) entre 3 salários e meio, 1 (7\%) 4 salários, 1 (7\%) entre 5 à 6 salários, 1 (7\%) 5 salários e 1 (7\%) 7 salários. Neste caso, a maioria tem renda familiar entre 3 a 5 salários e considerando que moram outras pessoas nas residências, e que várias destas trabalham, há um complemento na renda familiar.

Dos 14 aposentados rurais participantes da pesquisa, 5 (36\%) afirmaram que 1 pessoa trabalha na residência, 4 (29\%) nenhuma pessoa trabalha, 3 (21\%) 2 pessoas trabalham e 2 (14\%) 3 pessoas trabalham. Quando perguntado quantas pessoas moram na residência, 6 (43\%) responderam duas pessoas, 4 (29\%) três pessoas, $3(21 \%)$ quatro pessoas e 1 (7\%) uma pessoa, não houve nenhum caso que afirmou morar mais de 4 pessoas. Em relação ao parentesco dessas pessoas com os aposentados entrevistados, os mesmos são esposo (a), filhos e netos, não houve nenhum caso de genro/nora ou outro grau de parentesco. 
Gráfico 05 - Renda média familiar dos participantes da pesquisa.

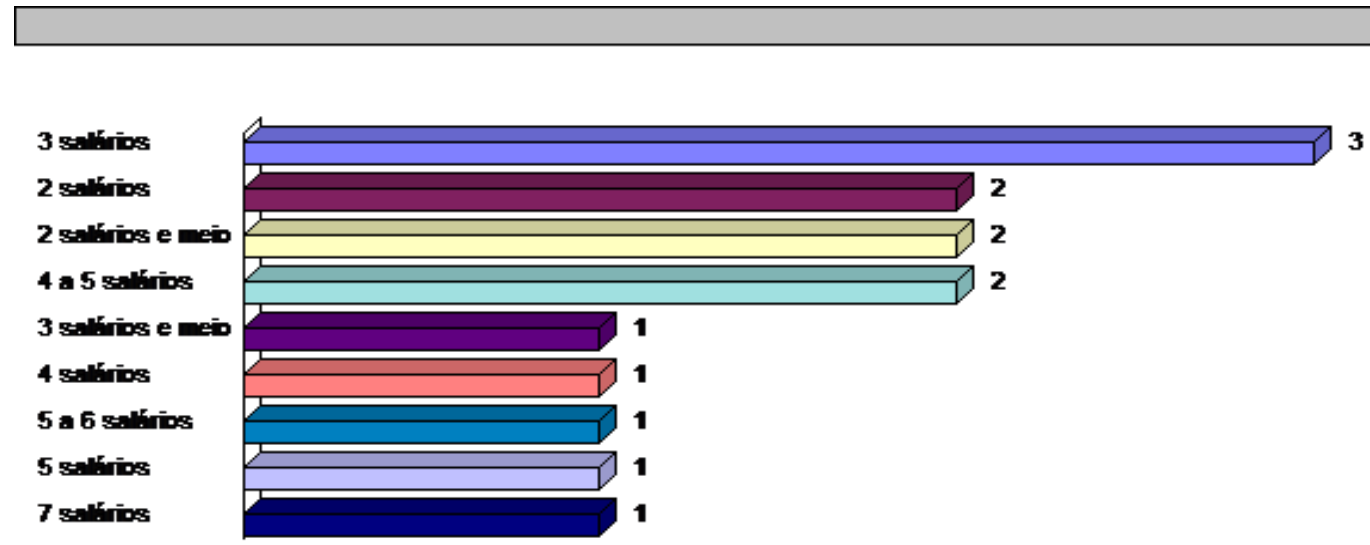

Fonte: Pesquisa de campo (2018)

No que se refere à quantidade de benefícios previdenciários recebidos na residência (gráfico 06) a maioria 9 (65\%) informaram receber 2 benefícios, sendo a esposa e o marido que residem na casa, ou o morador mais a pensão do falecido (a) no caso de viuvez, 3 (21\%) 1 benefício, sendo que nestes casos, o cônjuge ainda não alcançou a idade mínima para aposentar-se, 1 (7\%) 3 benefícios, sendo a esposa, o marido e uma filha que residem na mesma casa, e por fim 1 (7\%) 4 benefícios, sendo que ambos são viúvos e vivem em união estável, assim recebem seus benefícios e a pensão do (a) falecido (a) cônjuge. Não houve nenhum caso que afirmasse receber mais de 4 benefícios.

Sobre a quantidade de benefícios por residência é importante avaliar que dos 14 participantes da pesquisa, 11 (78.5\%), recebem mais de um benefício por residência, ou seja, podemos avaliar que os benefícios previdenciários representam um ganho representativo de renda a estas famílias.

\section{Gráfico 06 - Quantidade de benefícios previdenciários recebidos na residência}

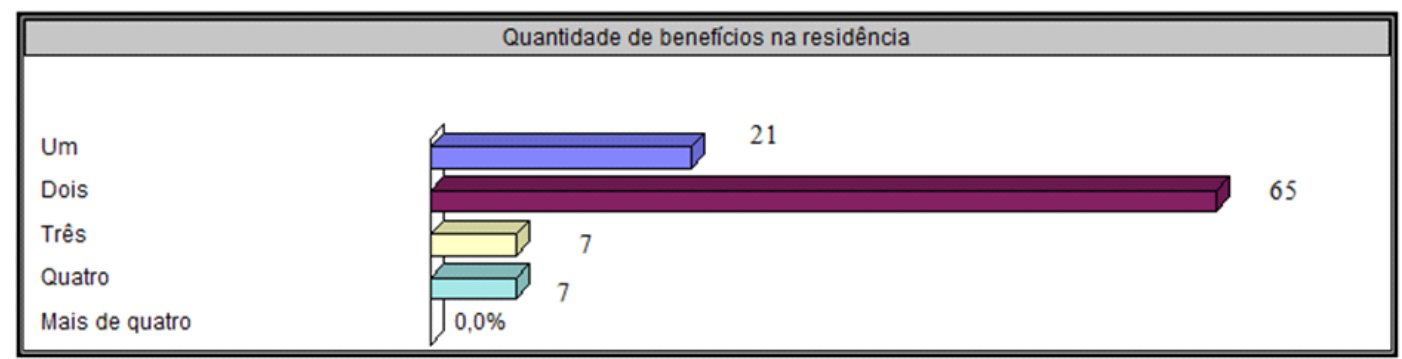

Fonte: Pesquisa de campo (2018). 
Em relação ao grau de dificuldade na concessão do benefício previdenciário, dos 14 participantes da pesquisa, 11 (79\%) afirmaram que não encontraram nenhuma dificuldade e 3 (21\%) afirmaram que sentiram um pouco de dificuldade. De acordo com os agricultores aposentados, a principal dificuldade consistiu em responder às perguntas da entrevista realizada na agência do Instituto Nacional do Seguro Social (INSS). Tal entrevista, denominada "entrevista rural" é uma das etapas que o solicitante deve atender para análise da concessão do benefício. Na ocasião, deve responder a uma série de questões sobre as atividades que desenvolve, demonstrando conhecimento sobre o ciclo da produção agropecuária, bem como a organização familiar do trabalho, o que corrobora para comprovar sua condição de produtor rural. Vale ressaltar que, nessa etapa, o técnico do INSS, se constatar incoerências em relação aos documentos apresentados e informações falsas, pode inclusive indeferir de imediato o benefício. Assim, compreendemos que essa fase causa certa tensão e receio em parte dos agricultores, levando-os a entender como uma dificuldade.

Uma segunda dificuldade apontada foi apresentar todos os documentos necessários para comprovação da atividade rural. No entanto, de modo geral, verifica-se que os agricultores familiares de Boa Esperança têm acesso às informações necessárias no que se refere ao trâmite de solicitação do benefício, já que a grande maioria dos participantes da pesquisa aponta não ter tido nenhuma dificuldade, porém, os dados também demonstram que uma quantidade significativa de agricultores, ainda têm dificuldades no acesso e/ou compreensão dessas informações, o que poderia ser amenizado com uma ação e/ou participação mais efetiva no sindicato da categoria.

Com o intuito de conhecer a relevância do benefício previdenciário na vida dos aposentados e familiares, elaboraram-se algumas questões direcionadas nesse sentido. Quando perguntado há quanto tempo recebem o benefício previdenciário (Gráfico 07), obteve-se 3 (21\%) que afirmaram receber entre 1 e 3 anos, 4 (29\%) entre 4 e 6 anos, 1 (7\%) entre 7 e 10 anos, 2 (14\%) entre 11 e 15 anos, 4 (29\%) entre 16 e 25 anos. Não houve nenhum caso de pessoa que recebesse há mais de 25 anos. 


\section{Gráfico 07 - Tempo de recebimento do benefício previdenciário}

Tempo de recebimento

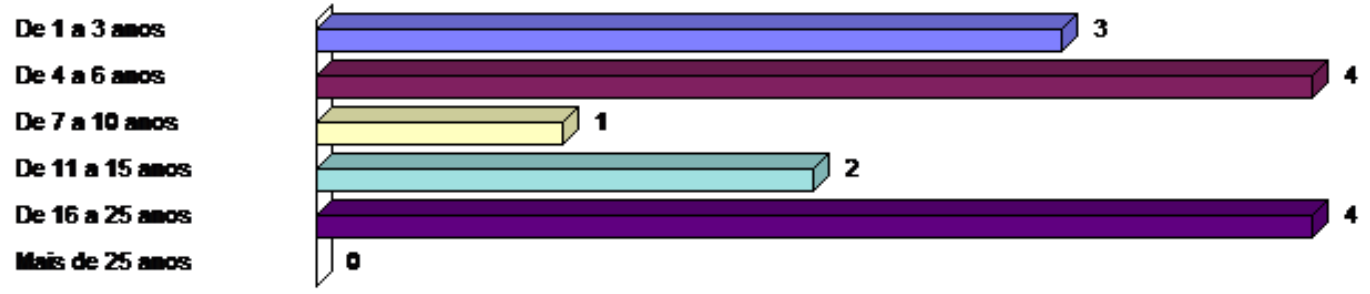

Fonte: Pesquisa de campo (2018).

Em relação à idade em que passaram a receber o benefício, todas as mulheres informaram 55 anos, exceto uma aposentada que recebeu auxílio doença dos 50 aos 55 anos, quando passou a receber a aposentadoria rural. Já os homens, todos afirmaram ter se aposentado aos 60 anos. No que diz respeito ao tipo de benefício que recebem (Gráfico 08), dos 14 participantes, 100\% afirmaram receber por idade. Desses 14, encontraram-se 2 casos que, além de seu benefício, recebem pensão por morte do cônjuge (ambos os casos o esposo quem faleceu). Esses dados mostram a importância da aposentadoria rural especial por idade, pois é facultativo ao agricultor realizar contribuições ao INSS (é muito raro casos em que a contribuição ocorre).

\section{Gráfico 08 - Tipo de benefício que recebem}

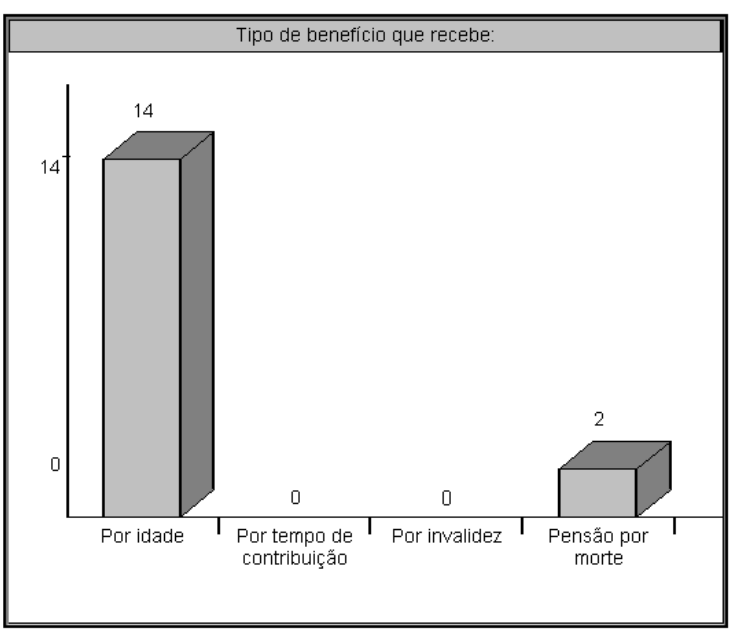

Fonte: Pesquisa de campo (2018). 
Quando questionados se o valor recebido com o benefício previdenciário mudou alguma coisa em suas vidas (Gráfico 09), 9 (65\%) afirmaram que mudou muito, pois se constitui em uma renda fixa e garantida, de forma que não ficam mais tão vulneráveis às condições do tempo atmosférico, da dinâmica dos mercados como quando a produção agropecuária era a única e/ou principal fonte de renda. Alguns entrevistados também ressaltaram que com o recebimento do benefício puderam melhorar a condição de vida, como, por exemplo, a alimentação, a moradia, o acesso a serviços de saúde e compra de remédios. 3 (21\%) disseram que houve mudança, mas foi regular e 2 (14\%) afirmaram que mudou muito pouco, porque o valor recebido é o mesmo valor de quando trabalhavam por dia, sendo assim, apenas mantém as mesmas condições de antes, ou seja, o necessário para manter o sustento. Nenhum dos entrevistados afirmou que não houve mudança alguma.

O dado revela que a grande maioria dos aposentados, participantes da pesquisa, considera que houve uma mudança positiva e relevante em suas vidas a partir do recebimento do benefício previdenciário, o que denota a importância da previdência rural especial na realidade desses idosos.

\section{Gráfico 09 - Mudanças na vida a partir do recebimento do benefício}

\section{Mudanças na vida}

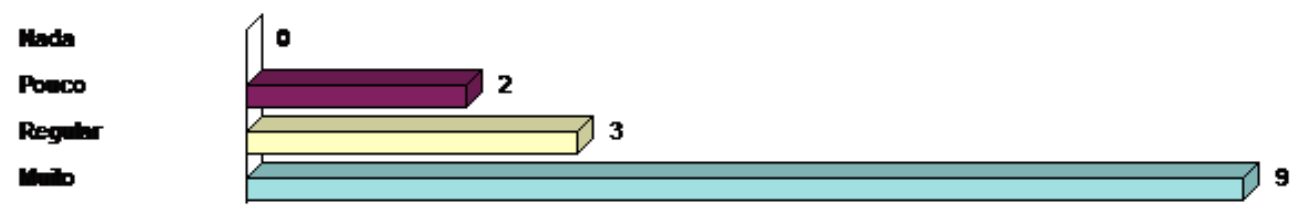

Fonte: Pesquisa de campo (2018).

Outro aspecto questionado aos aposentados foi se após aposentarem-se passaram a comprar algum produto que não compravam antes. Dos entrevistados, 8 (57\%) afirmaram que não. Fazem o uso do benefício para comprar o que já compravam antes. Enquanto 6 (43\%) afirmaram que sim. Puderam melhorar a sua casa, comprando móveis, fazendo reformas. Uma 
aposentada relatou que pôde começar a cuidar mais de si mesma, comprando protetor solar, tintura para o cabelo, roupas, calçados e que pretende fazer um tratamento odontológico.

Destacamos que dos 6 entrevistados que afirmaram comprar produtos que antes não compravam, todas são mulheres, o que podemos analisar como um ganho de autonomia financeira, visto que, no meio rural, tradicionalmente, os homens são responsáveis por administrar o dinheiro da família, o que impacta no poder de decisão das mulheres. Constatamos, assim, que, com o benefício previdenciário recebido com cartão próprio, mediante identificação pessoal da aposentada, as mesmas passam por um processo de empoderamento, ganho de autonomia e respeitabilidade em âmbito familiar e comunitário. Esse aspecto também foi constatado na pesquisa de Chies (2017).

Também foi questionado os principais itens com os quais os aposentados gastam o valor recebido com o benefício previdenciário (Gráfico 10). A questão permitia múltiplas respostas.

\section{Gráfico 10 - Principais gastos com o recurso da aposentadoria}

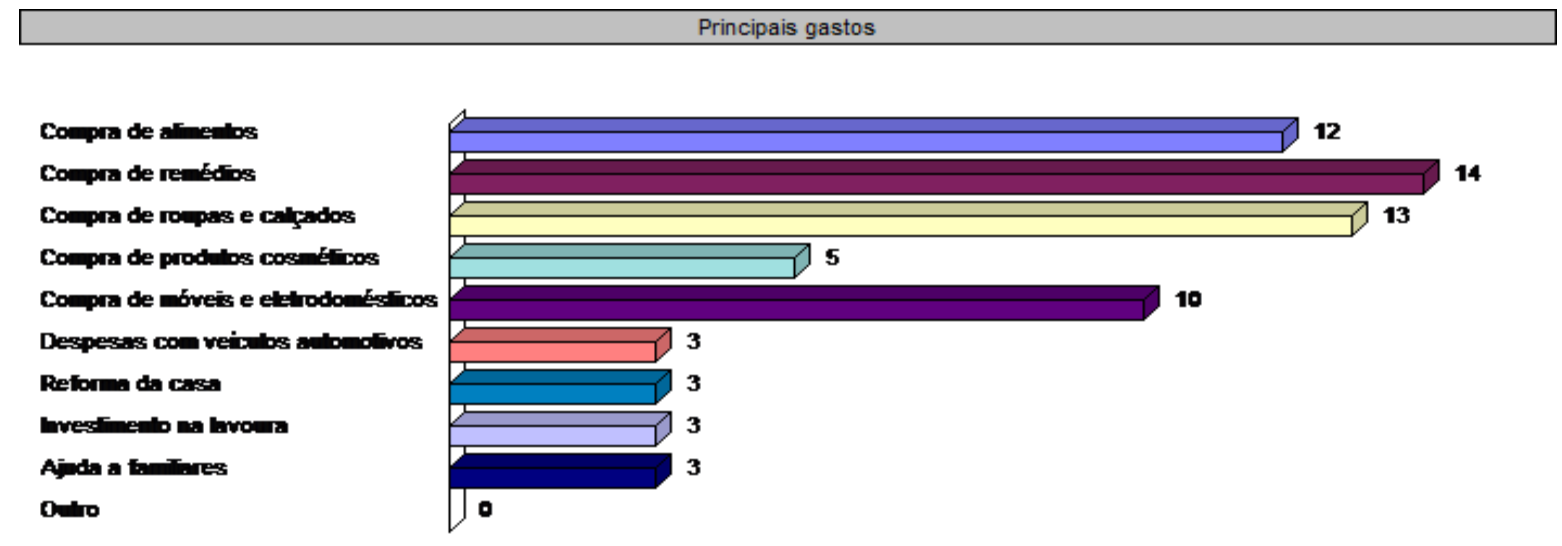

Fonte: Pesquisa de campo (2018). 
É possível verificar, por meio do Gráfico 8, que os recursos da aposentadoria são utilizados, em sua maioria, para as necessidades básicas da família, como alimentos, remédios, roupas e calçados e produtos de higiene pessoal. Destaca-se que todos os participantes afirmaram utilizar o dinheiro do benefício para compra de remédios, o que demonstra o impacto desse recurso para a busca da melhoria das condições de saúde desse grupo. Pode-se entender, também, que proporciona mais comodidade e conforto, considerando que 10 (71\%) dos aposentados afirmaram já ter comprado móveis e eletrodomésticos com esse recurso. Nos trabalhos de campo, ouviu-se vários relatos da possibilidade proporcionada pela aposentadoria de adquirir móveis e eletrodomésticos novos e como tal fato é valorizado por esse público.

Além disso, 3 participantes (21\%) afirmaram utilizar o recurso para despesas com veículos automotivos, reforma da casa, investimentos na lavoura e ajuda a familiares. Esse dado mostra que, apesar do baixo valor do salário mínimo que recebem, o mesmo tem um alcance representativo para proporcionar mais comodidade, melhora na residência, a reprodução da agricultura familiar e extrapola a figura do aposentado, impactando a vida de membros da família.

Portanto, verifica-se que há uma melhora nas condições de vida dos agricultores aposentados quando passam a receber o benefício previdenciário, pois melhoram as condições de moradia, alimentação, saúde, ou seja, passam a ter mais conforto. Vale destacar, como foi mencionado por alguns aposentados, que, devido à estabilidade financeira adquirida com a aposentadoria, o crédito no comércio local é facilitado, ampliando o poder de compra.

Com o direito ao recebimento do benefício, os aposentados também passaram a receber o $13^{\circ}$ salário. Assim, questionou-se como o recurso do $13^{\circ}$ 
salário costuma ser aplicado. Sendo essa uma questão aberta, obteve-se como respostas: 9 pessoas (65\%) afirmaram que o dinheiro chega no período de festas, então é gasto nas despesas da casa que aumentam devido à visita de familiares. Além disso, compram presentes, especialmente para netos(as); 2 pessoas afirmaram ajudar os familiares, 1 pessoa afirmou gastar com remédios, geralmente; 4 pessoas afirmaram fazer uma reserva para situações de emergência e 1 entrevistado afirmou ainda não ter recebido, pois se aposentou recentemente.

Vale destacar o relato interessante de um aposentado que, durante os trabalhos de campo, explicou que utilizou o recurso do décimo terceiro salário do ano anterior para viajar com a família e conhecer o mar. Ele se mostrou muito satisfeito com a oportunidade que teve e disse estar planejando outra viagem. Nesse caso, ele usufruiu desse recurso para uma atividade de lazer, aspecto também fundamental para a melhora das condições de vida.

Com o intuito de avaliar o impacto da aposentadoria rural especial na dinamização do comércio local no município de Boa Esperança, realizaram-se algumas questões sobre o tema. Questionou-se aos aposentados participantes da pesquisa onde gastam a maior parte do benefício recebido. Como respostas, constatou-se que a grande maioria 10 (72\%) gastam no comércio local, 3 (21\%) gastam em cidades vizinhas (Juranda e Goioerê, também de porte pequeno) e 1 (7\%) em cidades polos regionais, no caso Campo Mourão (Gráfico 11). Também questionou-se qual seria o motivo da preferência em gastar no comércio local, ou em cidades vizinhas, ou em cidades polos regionais. Sendo uma questão que permitia várias respostas, obteve-se o seguinte resultado: por ser o local mais próximo (11 respostas), porque conhece e/ou confia nos comerciantes (4 respostas), porque oferecem crédito (3 respostas), porque tem melhor preço (4 
respostas), porque os produtos têm mais qualidade (1 resposta), outros motivos (1 resposta).

\section{Gráfico 11 - Local onde os aposentados gastam a maior parte do benefício}

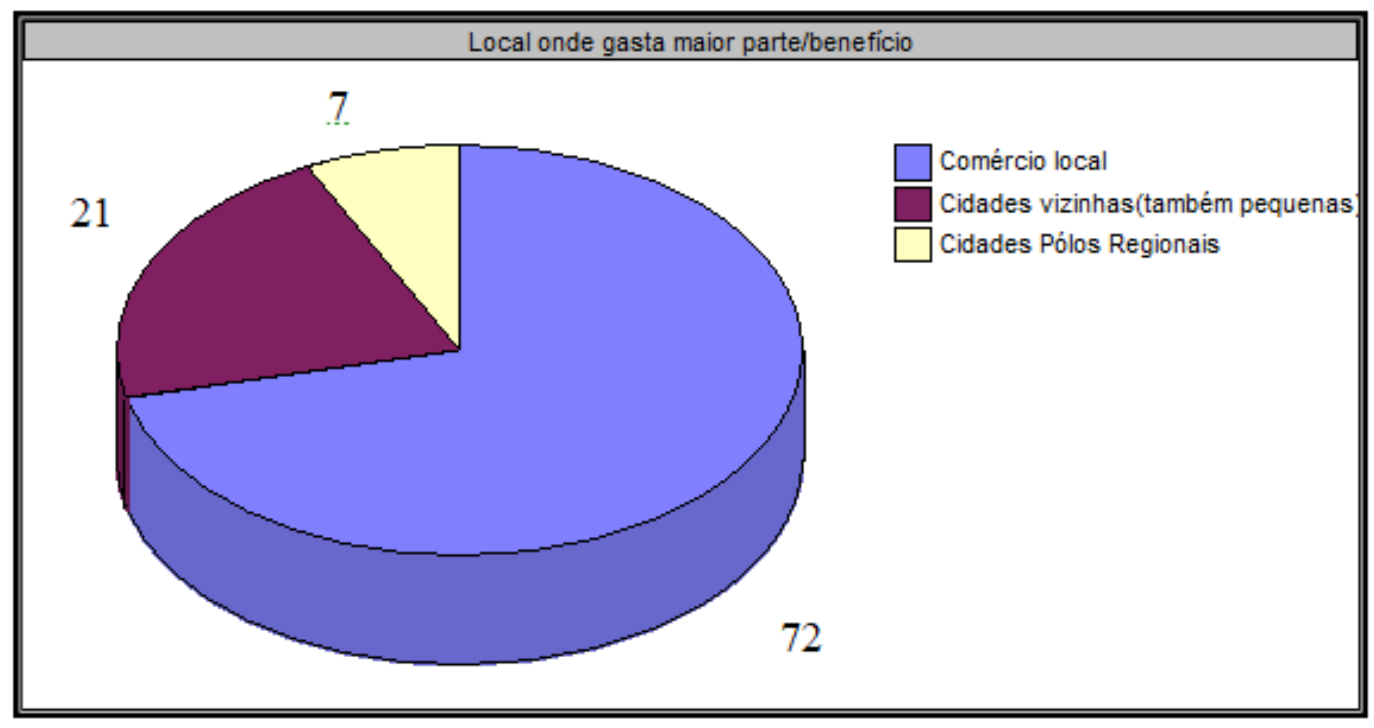

Fonte: Pesquisa de campo (2018).

A partir dos resultados, evidencia-se que os aposentados rurais promovem certo dinamismo para o comércio local, visto que a maioria procura por esse comércio devido a uma série de fatores, tais como: comodidade, proximidade, vínculos de amizade e oferta de crédito.

Além da aplicação dos questionários com os aposentados, para aprofundar as análises a respeito dos impactos das aposentadorias rurais no comércio local do município, realizaram-se entrevistas com alguns comerciantes. Os relatos dos comerciantes mostraram a importância do público idoso para o comércio. De acordo com Marques, proprietário de uma loja de móveis,

Há representatividade de aposentados no comércio, clientela muito grande, um público que paga certinho, cativo. Compram mais a linha de móveis e eletrodomésticos. Hoje tem as parcelas que facilitam a compra para eles. Vejo um impacto de pelo menos 30\% das vendas ao público idoso. Por ter essa renda fixa gastam mais no comércio local do que para fora (informação oral). 
Também para Zanim, proprietário de um supermercado "Os aposentados em geral são importantes com relação às vendas do meu comércio, um público presente, que paga certinho, fiel. Compram produtos alimentícios em geral. Gastam no município" (informação oral). Já Cioni, proprietário de uma farmácia, relata: "Há uma demanda grande de aposentados para o comércio, público cativo, adimplente, compram mais remédios. Gastam mais no comércio local, devido à locomoção, proximidade" (informação oral).

Rebequi, que é proprietário de um supermercado, corrobora essas opiniões ao relatar que em

Se tratando de Boa Esperança hoje, [os idosos são] uma das maiores fontes de renda para o mercado. Clientela classificada devido aos 20 anos de mercado, são pontuais, pagam direitinho, são cativos. Gastam o essencial com alimentação, buscam mais o próprio município, até mesmo pelo poder aquisitivo deles. É uma empresa que disponibiliza veículo e transporte para eles, até ganhei clientes por disponibilizar esse transporte. Coloquei um motorista mais de idade, pensei em alguém que pudesse ser um bom funcionário e que pudesse ganhar voto de confiança dos aposentados para a empresa. (informação oral).

Ao estudar sobre a importância da previdência rural para o dinamismo econômico e o desenvolvimento local de municípios com pequenas cidades da região noroeste do Paraná, Chies (2017) averiguou que os aposentados promovem certo dinamismo nos comércios locais e os principais fatores para isso são: a proximidade, facilidade e comodidade; a valorização dos vínculos de amizade e conhecimento com os comerciantes locais; a oferta de crédito; a dificuldade de locomoção para cidades maiores. Ainda sobre o exposto, ressaltase que os aposentados, na grande maioria das vezes, constituem uma clientela cativa e adimplente para os comércios locais, o que também foi constatado no município de Boa Esperança.

Já em uma visão mais geral do município, Santos, colonizador e ex-prefeito do município por 4 mandatos, avaliou que 95\% do dinheiro dos aposentados gira no comércio local. Ressaltou, ainda, que acredita que há uma tendência do município ter mais idosos, porque os jovens saem para estudar e trabalhar fora, 
o que ele acredita ser uma tendência nos municípios de pequeno porte. Também diz que vê certo retorno de pessoas para o município depois que se aposentam, pois, em sua visão, tanto a gestão atual como a anterior, visaram estruturar o município, principalmente em relação à saúde e projetos que atendam ao público de idosos, como por exemplo, o clube da melhor idade que já funciona há mais ou menos 15 anos (informação oral).

Outra análise interessante colocada por Santos é que, no montante dos recursos do município, as aposentadorias rurais representam um valor pouco significativo, porém, de acordo com seu entendimento, as pessoas de maior poder aquisitivo consomem mais fora do município, em cidades maiores, enquanto que os aposentados compram predominantemente no comércio local, fortalecendo-o e mantendo-o (informação oral).

Portanto, diante dos levantamentos realizados, averigua-se que os aposentados rurais têm um peso importante para a manutenção e o fortalecimento do comércio local de Boa Esperança, assim como verificado em outros municípios com pequenas cidades, o que contribui para dinamizar processos de desenvolvimento local.

\section{CONSIDERAÇÕES FINAIS}

Com o desenvolvimento da pesquisa a respeito dos aposentados rurais no município de Boa Esperança, averígua-se que entre as principais características socioeconômicas dos aposentados rurais: são proprietários de pequenas áreas de terra; possuem baixa escolaridade e forte enraizamento territorial; a renda familiar está entre 3 e 5 salários mínimos; a maioria recebe dois benefícios previdenciários por residência, o que amplia significativamente a renda familiar e a maioria também afirma não ter tido dificuldades para se aposentar.

No tocante à melhoria das condições de vida após aposentadoria, concluiu se que, mesmo o valor do benefício de um salário mínimo sendo considerado 
pouco pelos participantes da pesquisa, devido a todo o período da vida dedicado ao trabalho, o recebimento do mesmo é de grande importância na vida dessas pessoas, pois se constitui em uma renda fixa, que representa segurança e estabilidade, trazendo melhorias nas condições de vida, tanto do beneficiado como de familiares. As melhorias se referem à alimentação, às condições da habitação (com reformas na casa e aquisições de móveis e eletrodomésticos), acesso a tratamentos de saúde, ganho de autonomia financeira, principalmente por parte das mulheres, dentre outros.

Ademais, salienta-se que a aposentadoria rural especial tem impacto na dinamização e desenvolvimento do comércio do município, ressaltando que os próprios comerciantes reconhecem essa importância e alguns até fazem o uso de estratégias para ganhar a confiança dessa clientela, visto que os aposentados são considerados um público cativo e adimplente, por isso, essencial no comércio.

Por fim, considera-se que a aposentadoria rural especial tem um impacto fundamental, tanto para os beneficiários quanto para familiares, na dinâmica econômica dos municípios, especialmente para o comércio local daqueles com pequenas cidades.

\section{REFERÊNCIAS}

ALBUQUERQUE, F. J. B.; LÔBO, A. L.; RAYMUNDO, J. S.. Análise das repercussões psicossociais decorrentes da concessão de benefícios rurais. Psicologia Reflexão e Crítica. v.12, n.2, Porto Alegre, 1999.

ALVES, J. E. D. A transição demográfica e a janela de oportunidade. São Paulo: Instituto Fernand Braudel de Economia Mundial, 2008.

AUGUSTO, H. A.; RIBEIRO, E. M. O envelhecimento e as aposentadorias no ambiente rural: um enfoque bibliográfico. Organizações Rurais \& Agroindustriais. Lavras, v. 7, n. 2, p. 199-208, maio-agosto, 2005, Universidade Federal de Lavras, Brasil.

BRASIL. Constituição (1988). Constituição da República Federativa do Brasil. Brasília, DF: Senado, 1988. em: <http://www.planalto.gov.br/ccivil 03/constituicao/constituicao.htm>. Acesso em: 28 dez. 2019 
CHIES, C. Aposentadoria rural e políticas públicas para a agricultura familiar: estudo dos municípios de Guaporema, São Tomé, Tapejara e Tuneiras do Oeste - PR. 2017. 334 f. Tese (Doutorado em Geografia) - Universidade Estadual de Maringá, Maringá , 2017.

COSTA, F. R. A noção de municípios periféricos: contradições e desigualdades no estado do Paraná. 2013. 215 f. Tese (Doutorado em Geografia) - Universidade Estadual de Maringá, Maringá, 2013.

DELGADO, G. C.; CARDOSO JR. J. C. O idoso e a previdência rural no Brasil: a experiência recente da universalização. Brasília: IPEA, 1999.

FRANÇA, Á. S. Previdência social e a economia dos municípios. 5. ed. Brasília: ANFIP, 2004.

GIL, A. C. Métodos e Técnicas de pesquisa social. 6. ed. São Paulo: Atlas, 2008.

INSTITUTO BRASILEIRO DE GEOGRAFIA E ESTATÍSTICA - IBGE. 2010. Cidades. Disponível em:<http://cidades.ibge.gov.br/painel/populacao.php?lang=\&codmun=410300\&search=paran a|boa-esperanca|infogr\%E1 ficos:-evolu\%E7\%E3o-populacional-e-pir\%E2mide-et\%E1 ria>.

Acesso em: 01 ago. 2017.

INSTITUTO PARANAENSE DE DESENVOLVIMENTO ECONÔMICO E SOCIAL - IPARDES. Caderno Estatístico Município de Boa Esperança, 2017.

PREFEITURA MUNICIPAL DE BOA ESPERANÇA - PR. Histórico da Cidade. Disponível em: $<$ http://boaesperanca.pr.gov.br/site/prefeitura/conheca-nossa-cidade/historico-da-cidade/ >. Acesso em: ago. 2017.

SCHWARZER, H. Impactos socioeconômicos do sistema de aposentadorias rurais no Brasil - evidências empíricas de um estudo de caso no estado do Pará. Instituto de Pesquisa Econômica Aplicada - Ipea. Rio de Janeiro, 2000. 